\title{
Diversity of lactic acid bacteria associated with traditional fermented dairy products in Mongolia
}

\author{
J. Yu, ${ }^{1}$ W. H. Wang, ${ }^{1}$ B. L. G. Menghe, M. T. Jiri, H. M. Wang, W. J. Liu, Q. H. Bao, Q. Lu, J. C. Zhang, F. Wang, \\ H. Y. Xu, T. S. Sun, ${ }^{2}$ and H. P. Zhang ${ }^{2}$ \\ Key Laboratory of Dairy Biotechnology and Engineering, Education Ministry of P. R. China, Inner Mongolia Agricultural University, Hohhot, \\ Inner Mongolia 010018, P. R. China
}

\begin{abstract}
Spontaneous milk fermentation has a long history in Mongolia, and beneficial microorganisms have been handed down from one generation to the next for use in fermented dairy products. The objective of this study was to investigate the diversity of lactic acid bacteria (LAB) communities in fermented yak, mare, goat, and cow milk products by analyzing 189 samples collected from 13 different regions in Mongolia. The LAB counts in these samples varied from 3.41 to $9.03 \log \mathrm{cfu} / \mathrm{mL}$. Fermented yak and mare milks had almost identical mean numbers of LAB, which were significantly higher than those in fermented goat milk but slightly lower than those in fermented cow milk. In total, 668 isolates were obtained from these samples using de Man, Rogosa, and Sharpe agar and M17 agar. Each isolate was considered to be presumptive LAB based on grampositive and catalase-negative properties, and was identified at the species level by $16 \mathrm{~S}$ rRNA gene sequencing, multiplex PCR assay, and restriction fragment length polymorphism analysis. All isolates from Mongolian dairy products were accurately identified as Enterococcus faecalis (1 strain), Enterococcus durans (3 strains), Lactobacillus brevis (3 strains), Lactobacillus buchneri (2 strains), Lactobacillus casei (16 strains), Lactobacillus delbrueckii ssp. bulgaricus (142 strains), Lactobacillus diolivorans (17 strains), Lactobacillus fermentum (42 strains), Lactobacillus helveticus (183 strains), Lactobacillus kefiri (6 strains), Lactobacillus plantarum ssp. plantarum (7 strains), Lactococcus lactis ssp. lactis (7 strains), Leuconostoc lactis (22 strains), Leuconostoc mesenteroides (21 strains), Streptococcus thermophilus (195 strains), and Weissella cibaria (1 strain). The predominant LAB were Strep. thermophilus and $L b$. helveticus, which were isolated from all sampling sites. The results demonstrate that traditional fermented
\end{abstract}

Received August 16, 2010.

Accepted March 18, 2011.

${ }^{1} \mathrm{~J}$. Yu and W. H. Wang contributed equally to this study.

${ }^{2}$ Corresponding authors: hepingdd@vip.sina.com and sts9940@sina. com dairy products from different regions of Mongolia have complex compositions of LAB species. Such diversity of LAB provides useful information for further studies of probiotic strain selection and starter culture design, with regard to the industrial production of traditional fermented milk.

Key words: traditional fermented dairy product, lactic acid bacteria, 16S rRNA gene

\section{INTRODUCTION}

In Mongolia, a large landlocked country in northeast Asia, approximately $40 \%$ of the population lives in the countryside as nomadic herders. The livelihood and well-being of Mongolians depend mainly on livestock and on milk in particular (Fratkin, 2005). Milk is sacred in Mongolia, where milk and milk products are staple foods that are produced in great abundance from the country's 30 million cattle, yaks, camels, horses, goats, and sheep (Sternberg, 2008). The traditional methods and processes for producing a range of specific products have been handed down through generations; thus, traditional milk products represent huge wealth and an important part of Mongolian heritage.

Fermented mare milk is a very popular traditional beverage in Mongolia, and it is rich in ferments (lactic acid bacteria and yeast), trace elements, antibiotics, vitamins $\mathrm{A}, \mathrm{B}_{1}, \mathrm{~B}_{2}, \mathrm{~B}_{12}, \mathrm{C}$, D, and $\mathrm{E}$, ethyl alcohol, lactic acid, and carbonic acid (Abdel-Salam et al., 2010). Mongolians use fermented mare milk for medical purposes, for recovering strength, and as a cure for diseases of digestive organs and illnesses such as tuberculosis (Solaroli et al., 1993; Lozovich, 1995; Geerlings et al., 2006). As the major livestock species, sheep and goats provide most of the milk and dairy products. Goat milk has been described as having greater digestibility and lower allergenic properties than cow milk, and it has been attributed with certain therapeutic values in human nutrition (Barrionuevo et al., 2002; Martín-Diana et al., 2003). Fermented yak milk and cow milk are widely consumed by local herders in Mongolia.

All of these milk products have typical features that depend on local and regional traditions. In addition, 
raw material-associated lactic acid bacteria (LAB) have an essential role in the nutritious and organoleptic properties of fermented milk production (Caplice and Fitzgerald, 1999). Spontaneous milk fermentation has a long history in Mongolia, and many milk products are still fermented on the household scale. The indigenous microorganisms, which depend on the raw milk, environment, and technology conditions, are considered to play a major role in determining the typical features of traditional fermented milk products. These microorganisms have the ability to lower the $\mathrm{pH}$ of a mixture by producing acid from sugars, leading to the development of the desirable organoleptic properties (Corsetti et al., 2007).

A few previous studies have examined LAB and yeasts isolated from samples of fermented milk in Mongolia. Uchida et al. (2007) analyzed the LAB composition of 3 "airag" (an alcoholic fermented horse milk), 2 "tarag" (fermented milk of cows, yaks, goats, or camels), 2 "isgelen tarag" and "qoormog" (prolonged fermentation products of tarag), and some cheeses collected from 3 nomadic families in the Donto-Govi prefecture of Mongolia. Watanabe et al. (2008) used culture- and molecular biology-based methods to identify $367 \mathrm{LAB}$ strains and 152 yeast strains isolated from 22 airag and 31 tarag samples in Mongolia. Lactobacillus casei, Lactobacillus delbrueckii ssp. bulgaricus, Lactobacillus fermentum, Lactobacillus kefiranofaciens, Lactobacillus plantarum ssp. plantarum, Lactococcus lactis ssp. cremoris, and Streptococcus thermophilus were the most commonly isolated species.

To obtain a complete overview of the indigenous LAB involved in natural fermented milk from various regions and different raw milks in Mongolia, we aimed to systematically study the diversity of LAB isolated from fermented yak, mare, goat, and cow products in Mongolia. Meanwhile, several molecular methods, such as $16 \mathrm{~S}$ rRNA gene sequencing analysis, species- or subspecies-specific PCR, and RFLP analysis were applied for a more rapid and reliable identification of a large number of isolates.

\section{MATERIALS AND METHODS}

\section{Collection of Samples}

Fermented milk samples and their collection sites are shown in Table 1. One hundred eighty-nine samples of traditional fermented milk were collected from individual households in 12 provinces and 1 city of Mongolia. About $2 \mathrm{~mL}$ of each fermented milk sample was aseptically collected and transported to our laboratory in a $4^{\circ} \mathrm{C}$ vehicle-mounted refrigerator. Subsequently, all of the samples were analyzed within a few hours.

\section{Enumeration, Isolation, and Phenotypic Characterization of Isolates}

One milliliter of milk sample was mixed with $9 \mathrm{~mL}$ of $0.85 \%$ (wt/vol) sterile physiological saline to make an initial dilution $\left(10^{-1}\right)$. Serial dilutions were made for each sample and $0.1 \mathrm{~mL}$ of the appropriate dilution $\left(10^{-4}, 10^{-5}\right.$, and $\left.10^{-6}\right)$ spread plated in triplicate on media. Plate count agar with bromocresol purple (BCP; Nissui Ltd., Tokyo, Japan) was incubated at $30^{\circ} \mathrm{C}$ for $48 \mathrm{~h}$ for enumeration of the total LAB under

Table 1. Samples, lactic acid bacteria (LAB) counts, and sampling locations in Mongolia

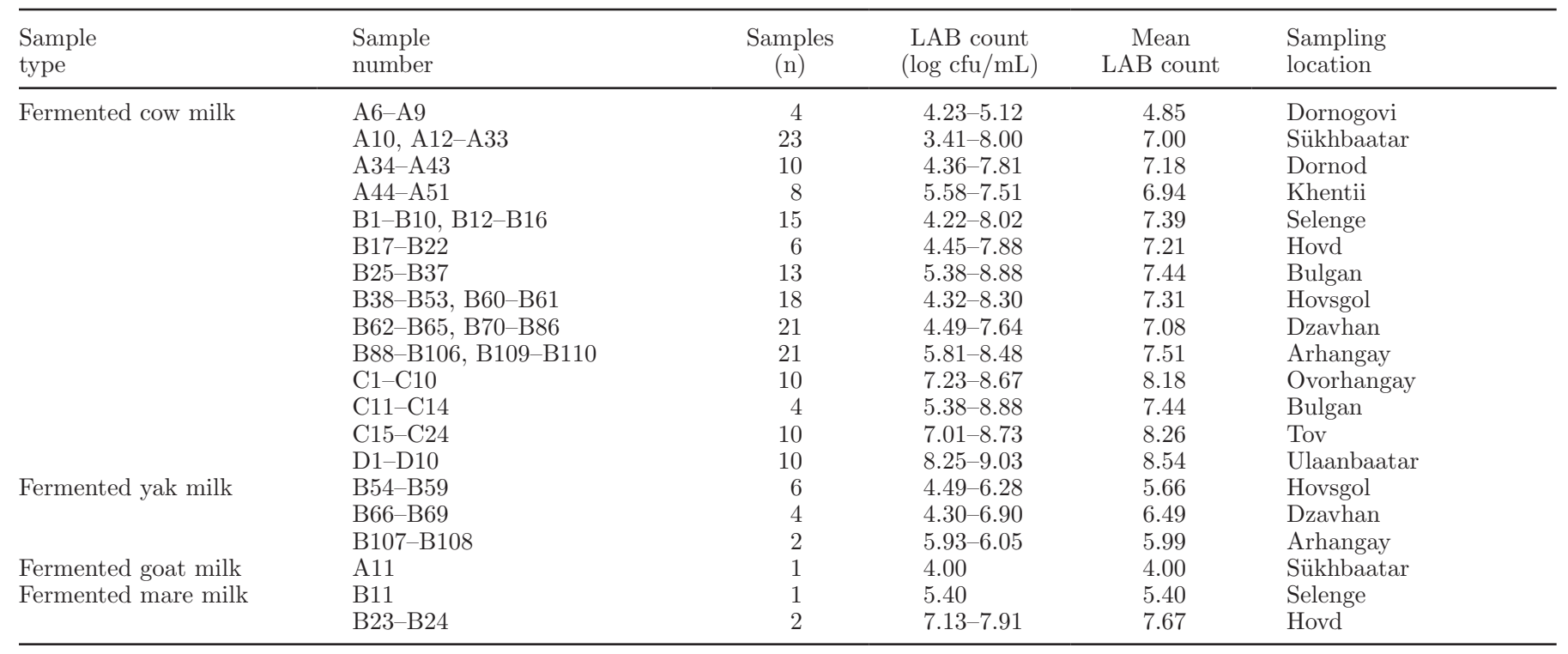


anaerobic conditions. Cycloheximide at a concentration of $0.01 \%$ ( $\mathrm{vol} / \mathrm{vol}$ ) was added to the BCP plates to prevent fungal growth. After incubation, colonies were enumerated and recorded as colony forming units per milliliter of milk. de Man, Rogosa, and Sharpe agar (MRS; Difco Laboratories, Detroit, MI) and M17 (Oxoid Ltd., Basingstoke, UK) plates were incubated anaerobically at $30^{\circ} \mathrm{C}$ for $48 \mathrm{~h}$. Colonies with distinct morphological differences (color, shape, and size) were selected and purified by streaking on the same medium. The catalase and Gram reactions of all the isolates were assessed, and gram-positive, catalase-negative isolates were preserved in milk containing $0.1 \%$ sodium glutamate and stored at $-80^{\circ} \mathrm{C}$. A representative isolate in each species were tested for gas production from glucose, salt tolerance $(3.0 \%$ and $6.5 \%)$, growth at different temperature $\left(5,10,45\right.$, and $\left.50^{\circ} \mathrm{C}\right)$ and $\mathrm{pH}(3.0$, 3.5, 4.0, and 7.0) in MRS broth, as described by Kozaki et al. (1992).

\section{DNA Extraction and 16S rRNA Gene Sequencing}

Total genomic DNA was extracted from overnight cultures by using a previously reported method (Yu et al., 2009). Purified DNA was diluted to a final concentration of $100 \mathrm{ng} / \mu \mathrm{L}$ for application. All gram-positive, catalase-negative bacterial isolates were preliminary identified by $16 \mathrm{~S}$ rRNA sequencing. For each strain, the genomic DNA was used as a template for PCR amplification of a segment of $16 \mathrm{~S}$ rRNA gene on the automatic thermal cycler (PTC-200, MJ Research, Waltham, MA). Primers and reaction mixtures are listed in Table 2. The sequencing of purified products was performed in Shanghai Sangni Biosciences Corporation of China (Shanghai). The sequences were analyzed and determined using the BLAST algorithm (http:// www.ncbi.nlm.nih.gov/blast; Altschul et al., 1997) and were submitted to the NCBI (http://www.blast. ncbi.nlm.nih.gov). Consensus sequences were imported into MEGA version 4.0 software (http://www.mega software.net; Tamura et al., 2007), with which a sequence alignment and phylogenetic trees were created based on the neighbor-joining (NJ) method. The percentage of bootstrap confidence levels for internal branches, as defined by the MEGA program, was calculated from 100 random ressamplings. Bacillus subtilis was used as an outgroup.

\section{Discrimination of Closely Related Species and Subspecies}

According to the partial sequences of $16 \mathrm{~S}$ rRNA gene, we used phylogenetic analysis to differentiate strains that belonged to the Lb. casei group (Lb. casei,
Lb. rhamnosus, and $L b$. zeae), the $L b$. plantarum group (Lb. paraplantarum, Lb. pentosus, and $L b$. plantarum ssp. plantarum, Lb. plantarum ssp. argentoratensis), Lb. delbrueckii, Lc. lactis, and Enterococcus species. These isolates were further classified by using PCR-RFLP techniques or subspecies-specific primers to verify the results of 16S rRNA gene sequence analysis.

The PCR-RFLP analysis of the gene encoding the elongation factor $\mathrm{Tu}$ (tuf gene) and 16S rRNA gene were used to discriminate $L b$. casei group and Lc. lactis, respectively. The PCR primers Tuf 1 , Tuf 2, Y1, and Y2 were used to amplify the tuf gene and $16 \mathrm{~S}$ rRNA gene (Table 2). Following amplification, the reaction mixtures were electrophoresed in $1 \%$ agarose gel in Tris-borate EDTA buffer (40 $\mathrm{m} M$ Tris/acetate, 1 $\mathrm{m} M$ EDTA, $\mathrm{pH}$ 8.0) at $100 \mathrm{~V}$ for $1 \mathrm{~h}$, and the gel was stained with ethidium bromide. Aliquots of $3 \mu \mathrm{L}$ of each amplified product were digested with restriction endonucleases as recommended by the manufacturer's protocols. Two restriction enzymes, RsaI and HaeIII (Takara Bio-Company, Shiga, Japan), were used in separate reactions. Restriction digests were analyzed through $5.0 \%$ polyacrylamide gel at $150 \mathrm{~V}$ for $1.5 \mathrm{~h}$ in $0.1 \times$ Tris-borate EDTA buffer. A DL2000 marker (Takara Bio-Company) was used as a size marker. Fragments shorter than $100 \mathrm{bp}$ were not considered in the analysis.

For further identification of $L b$. plantarum group, a multiplex PCR assay was performed with the recA gene-based primers paraF, pentF, planF, and pREV (Table 2). For accurate classification of $L b$. delbrueckii, representative strains within $L b$. delbrueckii were identified by using subspecies-specific primers, namely the proline iminopeptidase ( $\boldsymbol{p e p I P})$ gene-targeted primers LB1 and LLB1 (Table 2). For identification of Enterococcus faecium, Enterococcus durans, and Enterococcus faecalis, amplification of the 16S-23S rRNA gene intergenic transcribed spacer region (ITS) was performed as described previously (Fortina et al., 2003), using the primers G1 and L1 (Table 2).

\section{RESULTS}

\section{Enumeration of Isolates and Phenotypic Properties}

The viable counts of the $\mathrm{LAB}$ present in the samples are shown in Table1. Total counts of LAB in 173 fermented cow milk samples on BCP agar varied in the range from 3.41 to $9.03 \log \mathrm{cfu} / \mathrm{mL}$. The LAB counts in 12 fermented yak milk samples, 3 fermented mare milk samples, and 1 fermented goat milk sample ranged from 4.30 to $6.90 \log \mathrm{cfu} / \mathrm{mL}, 5.40$ to $7.91 \log \mathrm{cfu} / \mathrm{mL}$, and $4.00 \log \mathrm{cfu} / \mathrm{mL}$, respectively.

Gram-positive and catalase-negative bacteria growing on MRS and M17 agar were considered as presumptive 
Table 2. Oligonucleotide primers and PCR reactions used in this study

\begin{tabular}{|c|c|c|c|c|c|}
\hline Primer & Oligonucleotide sequence $\left(5^{\prime}-3^{\prime}\right)$ & $\begin{array}{l}\text { Composition of } \\
50-\mu \mathrm{L} \text { reaction }\end{array}$ & $\begin{array}{l}\text { PCR } \\
\text { cycles }\end{array}$ & $\begin{array}{l}\text { Target } \\
\text { (product size) }\end{array}$ & Reference \\
\hline $\begin{array}{l}27 \mathrm{f} \\
1495 \mathrm{R}\end{array}$ & $\begin{array}{l}\text { AGAGTTTGATCCTGGCTCAG } \\
\text { CTACGGCTACCTTGTTACGA }\end{array}$ & $\begin{array}{l}5.0 \mu \mathrm{L} \text { of } 10 \times \text { buffer, } 2 \mu \mathrm{L} \text { of } \\
\mathrm{dNTP} \text { mix, } 2 \mu \mathrm{L} \text { of each primer, } \\
200 \mathrm{ng} \text { of DNA, } 2.5 \mathrm{U} \text { of Taq }\end{array}$ & $\begin{array}{l}94^{\circ} \mathrm{C} / 1 \mathrm{~min} ; 58^{\circ} \mathrm{C} / 1 \\
\min ; 72^{\circ} \mathrm{C} / 2 \mathrm{~min} \\
30 \text { cycles }^{2}\end{array}$ & $\begin{array}{l}\text { 16S rRNA gene } \\
(1,500 \mathrm{bp})\end{array}$ & Weisburg et al., 1991 \\
\hline $\begin{array}{l}\text { Tuf1 } \\
\text { Tuf2 }\end{array}$ & $\begin{array}{l}\text { GATGCTGCTCCAGAAGA } \\
\text { ACCTTCTGGCAATTCAATC }\end{array}$ & $\begin{array}{l}5.0 \mu \mathrm{L} \text { of } 10 \times \text { buffer, } 2 \mu \mathrm{L} \text { of } \\
\text { dNTP mix, } 5 \mu \mathrm{L} \text { of each primer, } \\
200 \mathrm{ng} \text { of DNA. } 1 \text { U of Tag }\end{array}$ & $\begin{array}{l}95^{\circ} \mathrm{C} / 30 \mathrm{~s} ; 52^{\circ} \mathrm{C} / 30 \mathrm{~s} \\
72^{\circ} \mathrm{C} / 2 \mathrm{~min} ; 35 \text { cycles }^{2}\end{array}$ & tuf gene (800 bp) & Ventura et al., 2003 \\
\hline $\begin{array}{l}\text { paraF } \\
\text { pentF } \\
\text { planF } \\
\text { pREV }\end{array}$ & $\begin{array}{l}\text { GTCACAGGCATTACGAAAAC } \\
\text { CAGTGGCGCGGTTGATATC } \\
\text { CCGTTTATGCGGAACACCTA } \\
\text { TCGGGATTACCAAACATCAC }\end{array}$ & $\begin{array}{l}5.0 \mu \mathrm{L} \text { of } 10 \times \text { buffer, } 2 \mu \mathrm{L} \text { of dNTP } \\
\text { mix, } 2 \mu \mathrm{L} \text { of each primer, } 1 \mu \mathrm{L} \text { of primer } \\
\text { planF, } 200 \mathrm{ng} \text { of DNA, } 2.5 \mathrm{U} \text { of Taq }\end{array}$ & $\begin{array}{l}94^{\circ} \mathrm{C} / 30 \mathrm{~s} ; 56^{\circ} \mathrm{C} / 10 \mathrm{~s} \\
72^{\circ} \mathrm{C} / 30 \mathrm{~s} ; 30 \text { cycles }^{3}\end{array}$ & $\operatorname{rec} A$ gene & Torriani et al., 2001 \\
\hline $\begin{array}{l}\text { Y1 } \\
\text { Y2 }\end{array}$ & $\begin{array}{l}\text { TGGCTCAGGACGAACGCTGGCGGC } \\
\text { CCTACTGCTGCCTCCCGTAGGAGT }\end{array}$ & $\begin{array}{l}5.0 \mu \mathrm{L} \text { of } 10 \times \text { buffer, } 1.5 \mu \mathrm{L} \text { of } \\
\mathrm{dNTP} \text { mix, } 2 \mu \mathrm{L} \text { of each primer, } \\
200 \mathrm{ng} \text { of DNA, } 2.5 \mathrm{U} \text { of Taq }\end{array}$ & $\begin{array}{l}94^{\circ} \mathrm{C} / 45 \mathrm{~s} ; 55^{\circ} \mathrm{C} / 45 \mathrm{~s} ; \\
70^{\circ} \mathrm{C} / 1 \mathrm{~min} ; 35 \text { cycles }^{3}\end{array}$ & $\begin{array}{l}\text { 16S rRNA gene } \\
(348 \mathrm{bp})\end{array}$ & Young et al., 1991 \\
\hline $\begin{array}{l}\text { L1 } \\
\text { G1 }\end{array}$ & $\begin{array}{l}\text { CAAGGCATCCACCGT } \\
\text { GAAGTCGTAACAAGG }\end{array}$ & $\begin{array}{l}5.0 \mu \mathrm{L} \text { of } 10 \times \text { buffer, } 1.5 \mu \mathrm{L} \text { of } \\
\mathrm{dNTP} \text { mix, } 2 \mu \mathrm{L} \text { of each primer, } \\
200 \mathrm{ng} \text { of DNA, } 2.5 \mathrm{U} \text { of Taq }\end{array}$ & $\begin{array}{l}94^{\circ} \mathrm{C} / 1 \min ; 55^{\circ} \mathrm{C} / 2 \\
\min ; 72^{\circ} \mathrm{C} 3 \mathrm{~min} \\
25 \text { cycles }^{2}\end{array}$ & $\begin{array}{l}16 \mathrm{~S}-23 \mathrm{~S} \text { rDNA } \\
\text { intergenic } \\
\text { transcribed } \\
\text { spacer region }\end{array}$ & Fortina et al., 2003 \\
\hline $\begin{array}{l}\text { LB1 } \\
\text { LLB1 }\end{array}$ & $\begin{array}{l}\text { AAAAATGAAGTTGTTTAAAGTAGGTA } \\
\text { AAGTCTGTCCTCTGGCTGG }\end{array}$ & $\begin{array}{l}5.0 \mu \mathrm{L} \text { of } 10 \times \text { buffer, } 1 \mu \mathrm{L} \text { of } \\
\text { dNTP mix, } 2 \mu \mathrm{L} \text { of each primer, } \\
200 \mathrm{ng} \text { of DNA, } 2.5 \mathrm{U} \text { of Taq }\end{array}$ & $\begin{array}{l}94^{\circ} \mathrm{C} / 45 \mathrm{~s} ; 58^{\circ} \mathrm{C} / 30 \mathrm{~s} \\
72^{\circ} \mathrm{C} / 30 \mathrm{~s} ; 35 \text { cycles }^{4}\end{array}$ & pepIP gene & Torriani et al., 1999 \\
\hline
\end{tabular}

${ }^{1}$ Contained $10 \mathrm{p} M$ each primer; $10 \mathrm{~m} M$ dNTP mix (Takara Bio-Company, Shiga, Japan), Taq DNA polymerase (Takara Bio-Company).

${ }^{2}$ Initial denaturation at $94^{\circ} \mathrm{C}$ for $3 \mathrm{~min}$ and final extension of the amplified product at $72^{\circ} \mathrm{C}$ for 10 min.

${ }^{3}$ Initial denaturation at $94^{\circ} \mathrm{C}$ for $3 \mathrm{~min}$ and final extension of the amplified product at $72^{\circ} \mathrm{C}$ for 5 min.

${ }^{4}$ Initial denaturation at $94^{\circ} \mathrm{C}$ for $2 \mathrm{~min}$ and final extension of the amplified product at $72^{\circ} \mathrm{C}$ for $10 \mathrm{~min}$. 
LAB. In total, 668 presumptive LAB were isolated from 189 fermented milk samples. The majority of isolated strains were rod-shaped bacteria (398 isolates in total, with 307 isolates from MRS and 91 from M17 medium) and the remainders were cocci (270 isolates in total with 111 from MRS and 159 from M17 medium).

The characteristics of 16 representative LAB are shown in Table 3. All the isolates were homo- or heterofermentative rods or cocci, and these representative strains showed some different characteristics at the different growth conditions.

\section{S rRNA Gene Sequences Analysis}

The partial 16S rRNA gene sequences $(1,490 \mathrm{bp})$ of all the strains were determined. Then, the sequences were compared with related bacteria in GenBank and sequence similarities were determined using the BLAST program. According to the $16 \mathrm{~S}$ rRNA gene sequences, all strains were divided into 16 groups. As shown in Figures 1 and 2, a representative isolate in each group and their related type strains were used to construct a phylogenetic tree by using the MEGA 4.0 software. Isolates IMAU20130, IMAU20619, IMAU20680, IMAU20686, IMAU20159, and IMAU20683 showed proximity to $L b$. kefiri, $L b$. buchneri, $L b$. diolivorans, $L b$. brevis, $L b$. fermentum, and $L b$. helveticus, respectively, because they grouped on the phylogenetic tree together with the corresponding type strain. However, IMAU20113 appeared to be equally linked to both $L b$. plantarum ssp. plantarum and $L b$. pentosus, so the $16 \mathrm{~S}$ rRNA gene sequence did not give discriminatory results for this group. Isolate IMAU20365 shared 100\% identity with the $16 \mathrm{~S}$ rRNA gene sequence of $L b$. casei. Isolate IMAU20149 grouped with 4 subspecies Lb. delbrueckii ssp. bulgaricus, Lb. delbrueckii ssp. delbrueckii, Lb. delbrueckii ssp. indicus, and $L b$. delbrueckii ssp. lactics, and its 16S rRNA gene sequence showed a similarity of $100 \%$ to Lb. delbrueckii ssp. bulgaricus and over $99 \%$ to the other subspecies. As shown in Figure 2, IMAU20181, IMAU20309, IMAU20771, IMAU20141, IMAU20676, IMAU20243, and IMAU20244 were closely related to the type strains Leuconostoc lactis, Leuconostoc mesenteroides, Weissella cibaria, Strep. thermophilus, Lc. lactis ssp. lactis, E. faecalis, and E. durans, respectively.

The results confirmed that 668 strains belong to 6 genera (Enterococcus, Lactobacillus, Lactococcus, Leuconostoc, Weissella, and Streptococcus), 2 species groups, and 14 species: Lb. casei group, Lb. plantarum group, E. faecalis, E. durans, Lb. brevis, Lb. buchneri, $L b$. delbrueckii, $L b$. diolivorans, $L b$. fermentum, $L b$. helveticus, Lb. kefiri, Lc. lactis ssp. lactis, Leu. lactis, Leu. mesenteroides, Strep thermophilus, and W. cibaria (Table 4).

\section{Nucleotide Sequence Accession Numbers}

The GenBank/European Molecular Biology Laboratory (EMBL)/DNA Data Bank of Japan (DDBJ) accession numbers for the 16S rRNA gene sequences of 668 isolates were deposited under HM218005 to HM218007, HM218010 to HM218014, HM057851 to HM058157, HM058159 to HM058176, HM058178 to HM058309, HM058311 to HM058314, HM058316 to HM058322, HM058324 to HM058379, HM058381 to HM058516, respectively.

\section{Identification of Closely Related Species}

The partial tuf gene $(800 \mathrm{bp})$ and $16 \mathrm{~S}$ rRNA gene (348 bp) amplified from Lb. casei group, Lc. lactis ssp. lactis, and Lc. lactis ssp. cremoris were digested separately with the 2 restriction enzyme HaeIII and $R s a \mathrm{I}$ to ensure the identification of the isolates. The RFLP profiles are showed in Figure 3. The HaeIII patterns of isolates showed great differences among $L b$. casei, $L b$. zeae, and Lb. rhamnosus. The Y1-Y2 amplified fragment from Lc. lactis ssp. lactis digested with RsaI gave 2 products of 280 and $61 \mathrm{bp}$ (Figure 3), but the amplified fragment from Lc. lactis ssp. cremoris was not digested with RsaI. In addition, based on the $16 \mathrm{~S}$ rRNA gene sequences analysis, the representative isolate IMAU20676 was closer to the type strain Lc. lactis ssp. lactis than to the other 2 subspecies on the phylogenetic tree. Therefore, based on the results of RFLP and $16 \mathrm{~S}$ rRNA gene sequences analysis, 7 isolates were identified as Lc. lactis ssp. lactis.

The expected sizes of the amplicons were $318 \mathrm{bp}$ for Lb. plantarum ssp. plantarum, 218 bp for Lb. pentosus, and $107 \mathrm{bp}$ for $L b$. paraplantarum. Seven isolates in $L b$. plantarum group displayed a pattern characterized by the typical band of $L b$. plantarum ssp. plantarum (318 bp). All the $L b$. delbrueckii strains were identified as $L b$. delbrueckii ssp. bulgaricus with specific amplification product $(1,065 \mathrm{bp})$ by using pepIP gene-based primers (Figure 4). Primers G1 and L1 were used to amplify the 16S-23S rDNA ISR from genomic DNA of E. faecium, E. durans, E. faecalis, and 4 wild isolates (Figure 4).

\section{DISCUSSION}

The fermented milk samples analyzed in this study were produced using traditional and ancient methods of natural fermentation. These milk products vary depending on their quality, taste, ingredients, and production methods, which are unique among regions, provinces, and even families. Therefore, various beneficial microorganisms are present in different fermented milk products. We analyzed 189 samples to determine 
Table 3. Phenotypic characteristics of 16 representative strains isolated from traditional fermented milk in Mongolia $^{1}$

\begin{tabular}{|c|c|c|c|c|c|c|c|c|c|c|c|c|c|c|c|c|}
\hline \multirow[b]{2}{*}{ Characteristic } & \multicolumn{16}{|c|}{ Strain of each species ${ }^{2}$} \\
\hline & $\begin{array}{l}\text { IMAU } \\
20130\end{array}$ & $\begin{array}{l}\text { IMAU } \\
20619\end{array}$ & $\begin{array}{l}\text { IMAU } \\
20680\end{array}$ & $\begin{array}{l}\text { IMAU } \\
20365\end{array}$ & $\begin{array}{l}\text { IMAU } \\
20686\end{array}$ & $\begin{array}{l}\text { IMAU } \\
20113\end{array}$ & $\begin{array}{l}\text { IMAU } \\
20159\end{array}$ & $\begin{array}{l}\text { IMAU } \\
20149\end{array}$ & $\begin{array}{l}\text { IMAU } \\
20683\end{array}$ & $\begin{array}{l}\text { IMAU } \\
20243\end{array}$ & $\begin{array}{l}\text { IMAU } \\
20244\end{array}$ & $\begin{array}{l}\text { IMAU } \\
20676\end{array}$ & $\begin{array}{l}\text { IMAU } \\
20141\end{array}$ & $\begin{array}{l}\text { IMAU } \\
20771\end{array}$ & $\begin{array}{l}\text { IMAU } \\
20181\end{array}$ & $\begin{array}{l}\text { IMAU } \\
20309\end{array}$ \\
\hline Shape & Rod & Rod & Rod & Rod & Rod & Rod & Rod & Rod & Rod & Cocci & Cocci & Cocci & Cocci & Cocci & Cocci & Cocci \\
\hline Gram stain & + & + & + & + & + & + & + & + & + & + & + & + & + & + & + & + \\
\hline Gas from glucose & + & + & + & - & + & - & + & - & - & - & - & - & - & + & + & + \\
\hline Catalase & - & - & - & - & - & - & - & - & - & - & - & - & - & - & - & - \\
\hline \multicolumn{17}{|l|}{ Growth at $\mathrm{pH}$} \\
\hline 3.0 & - & - & - & - & - & $\mathrm{w}$ & - & - & + & - & - & - & - & - & - & - \\
\hline 3.5 & $\mathrm{w}$ & + & $\mathrm{w}$ & + & + & + & + & - & + & $\mathrm{w}$ & + & - & - & - & - & $\mathrm{w}$ \\
\hline 4.0 & + & + & + & + & + & + & + & + & + & + & + & $\mathrm{w}$ & - & + & + & + \\
\hline 7.0 & + & + & + & + & + & + & + & + & + & + & + & + & + & + & + & + \\
\hline \multicolumn{17}{|l|}{ Growth in $\mathrm{NaCl}$} \\
\hline $3.0 \%$ & + & + & + & + & + & + & + & + & + & + & + & + & + & + & + & + \\
\hline $6.5 \%$ & - & + & - & $\mathrm{w}$ & - & + & $\mathrm{w}$ & - & - & + & + & - & - & + & - & + \\
\hline \multicolumn{17}{|c|}{ Growth at temperature } \\
\hline $5^{\circ} \mathrm{C}$ & - & - & - & - & - & - & - & - & - & - & - & - & - & - & - & - \\
\hline $10^{\circ} \mathrm{C}$ & + & + & + & + & + & + & $\mathrm{w}$ & - & - & + & + & + & - & $\mathrm{w}$ & + & + \\
\hline $45^{\circ} \mathrm{C}$ & - & $\mathrm{w}$ & - & $\mathrm{w}$ & - & $\mathrm{w}$ & + & + & + & + & + & - & + & + & + & $\mathrm{w}$ \\
\hline $50^{\circ} \mathrm{C}$ & - & - & - & - & - & - & - & - & + & + & $\mathrm{w}$ & - & + & - & - & - \\
\hline
\end{tabular}

${ }^{2}$ IMAU20130 = Lactobacillus kefiri: IMAU20619 = Lactobacillus buchneri; IMAU20680 = Lactobacillus diolivorans; IMAU20365 = Lactobacillus casei; IMAU20686 = Lactobacillus brevis; IMAU20113 = Lactobacillus plantarum ssp. plantarum; IMAU20159 = Lactobacillus fermentum; IMAU20149 = Lactobacillus delbrueckii ssp. bulgaricus; IMAU20683 = Lactobacillus helveticus; IMAU20243 = Enterococcus faecalis; IMAU20244 = Enterococcus durans; IMAU20676 = Lactococcus lactis ssp. lactis; IMAU20141 = Streptococcus thermophilus; IMAU20771 = Weissella cibaria; IMAU20181 = Leuconostoc lactis; IMAU20309 = Leuconostoc mesenteroides. 


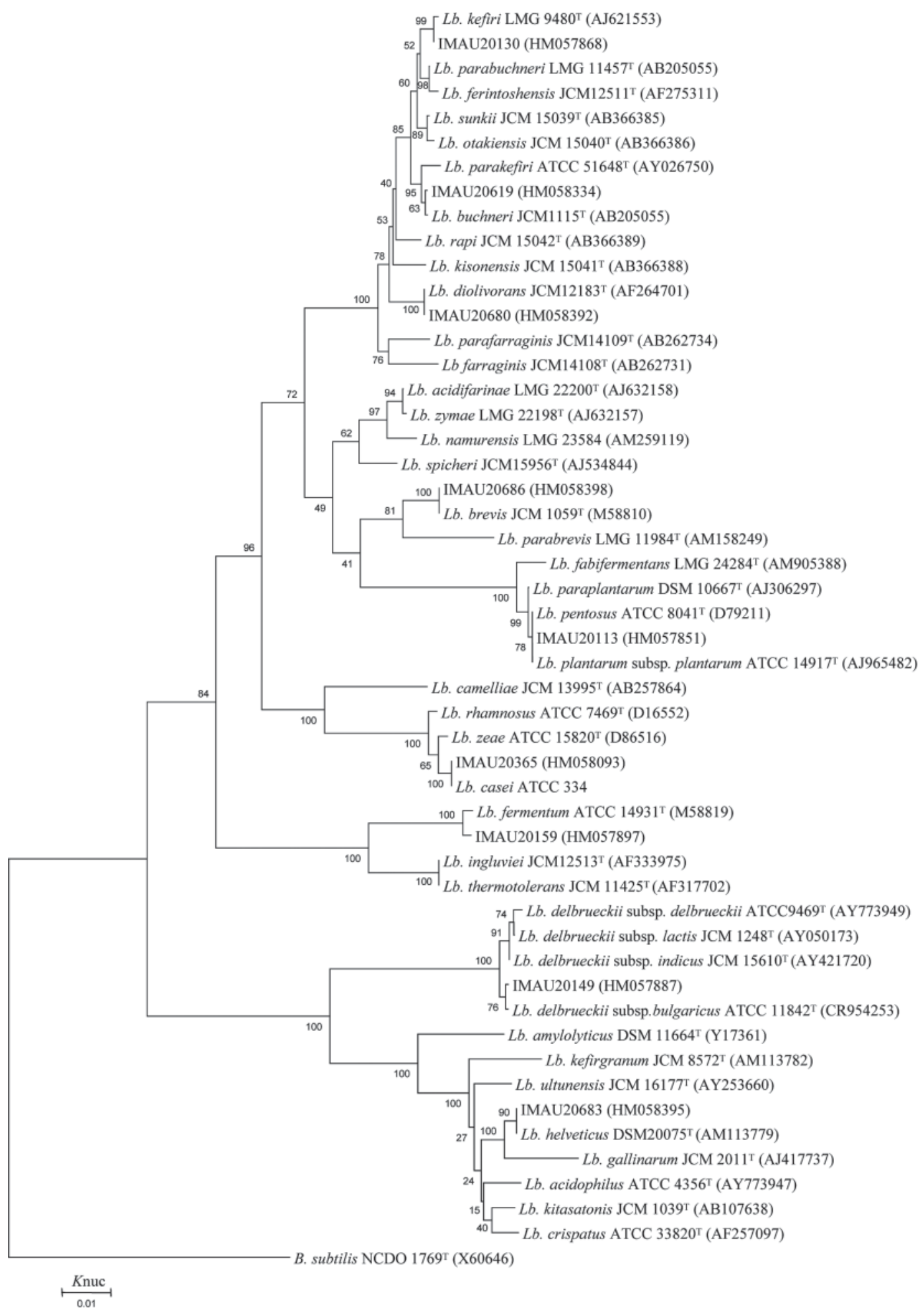

Figure 1. Neighbor-joining tree showing the phylogenetic relationships between 9 lactobacilli and the type strains based on 16S rRNA gene sequences. Bacillus subtilis is used as an outgroup. Numbers at the branch nodes are bootstrap values percentages (100 replicates) and the bar indicates $1 \%$ sequence divergence. $L b .=$ Lactobacillus. 


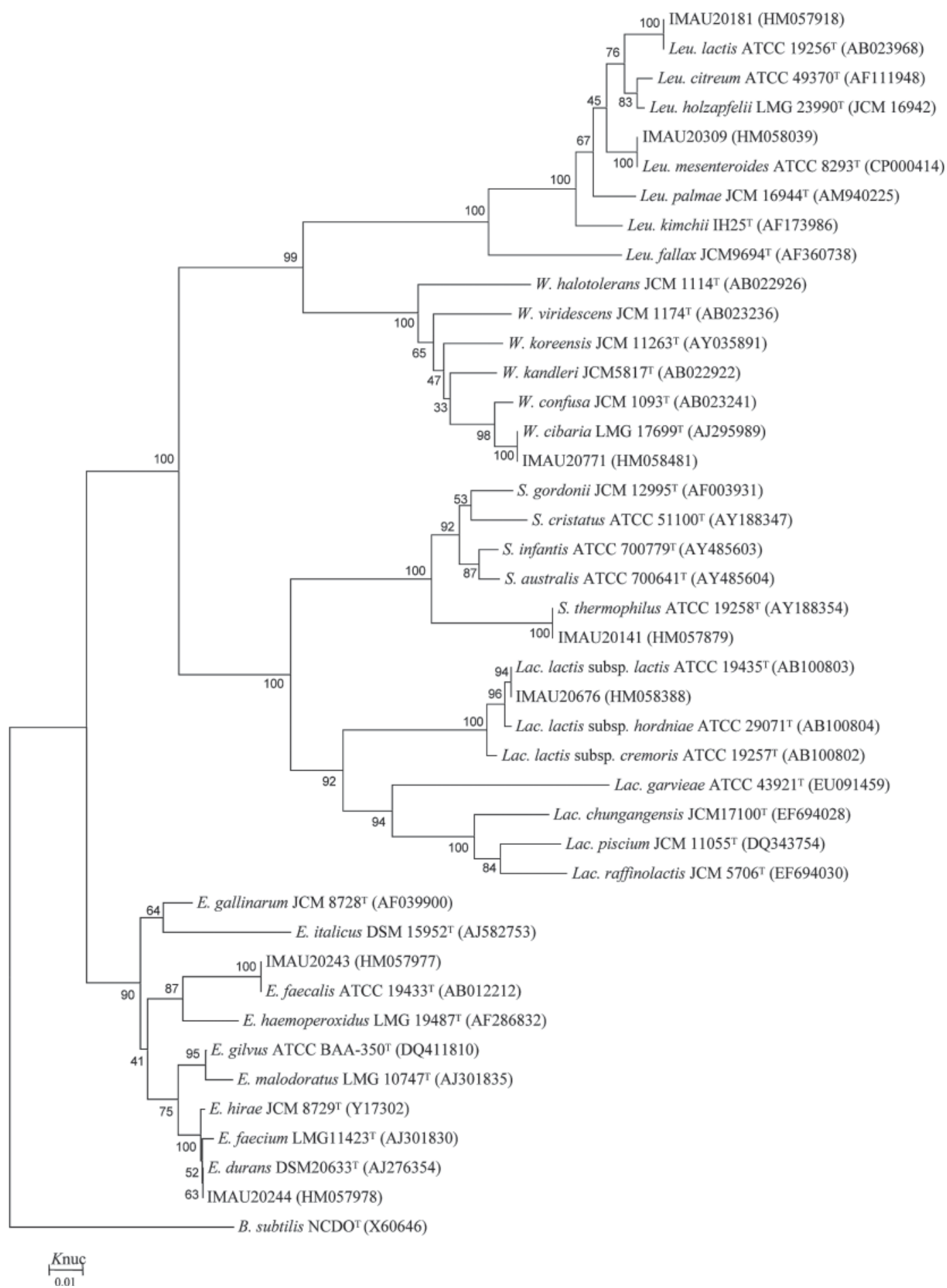

Figure 2. Neighbor-joining tree showing the phylogenetic relationships between 7 cocci and the type strains of related genera based on $16 \mathrm{~S}$ rRNA gene sequences. Bacillus subtilis is used as an outgroup. Numbers at the branch nodes are bootstrap values percentages (100 replicates) and the bar indicates $1 \%$ sequence divergence. E. = Enterococcus; Lac. $=$ Lactococcus $;$ Leu. $=$ Leuconostoc; S. $=$ Streptococcus; W. $=$ Weissella.

their LAB composition, with the aim of improving our understanding of specific characteristics of fermented milk products in Mongolia.
Slight variations of the viable counts of $\mathrm{LAB}$ were observed among fermented milk products of cow, yak, sheep, and mare. The mean numbers of LAB in fer- 
Table 4. Distribution of lactic acid bacteria (LAB) species in traditional fermented milk samples from different regions in Mongolia

\begin{tabular}{|c|c|c|c|c|c|c|c|c|c|c|c|c|c|c|}
\hline \multirow[b]{2}{*}{ LAB isolate } & \multicolumn{14}{|c|}{ Sampling location } \\
\hline & Dornogovi & Sükhbaatar & Dornod & Khentii & Selenge & Hovd & Bulgan & Hovsgol & Dzavhan & Arhangay & Ovorhangay & Tov & Ulaanbaatar & Total \\
\hline Enterococcus faecalis & & & & $1^{\mathrm{b}}$ & & & & & & & & & & $1^{\mathrm{b}}$ \\
\hline Enterococcus durans & & & & $1^{\mathrm{b}}$ & & & & & & & $1^{\mathrm{a}}+1^{\mathrm{b}}$ & & & $2^{\mathrm{a}}+1^{\mathrm{b}}$ \\
\hline Lactobacillus brevis & & & & & & & & & & & $2^{\mathrm{a}}+1^{\mathrm{b}}$ & & & $2^{\mathrm{a}}+1^{\mathrm{b}}$ \\
\hline Lactobacillus buchneri & & & & & $1^{\mathrm{a}}$ & & & & & $1^{\mathrm{b}}$ & & & & $1^{\mathrm{a}}+1^{\mathrm{b}}$ \\
\hline $\begin{array}{l}\text { Lactobacillus casei } \\
\text { Lactobacillus delbrueckii }\end{array}$ & & $8^{\mathrm{a}}$ & $16^{\mathrm{a}}+1^{\mathrm{b}}$ & $6^{\mathrm{a}}+1^{\mathrm{b}}$ & $14^{\mathrm{a}}+1^{\mathrm{b}}$ & $12^{\mathrm{a}}$ & $\begin{array}{c}1^{\mathrm{a}}+1^{\mathrm{b}} \\
12^{\mathrm{a}}+1^{\mathrm{b}}\end{array}$ & $\begin{array}{l}1^{\mathrm{a}} \\
19^{\mathrm{a}}+1^{\mathrm{b}}\end{array}$ & $\begin{array}{l}4^{\mathrm{a}}+8^{\mathrm{b}} \\
9^{\mathrm{a}}+2^{\mathrm{b}}\end{array}$ & $\begin{array}{l}1^{\mathrm{b}} \\
6^{\mathrm{a}}+3^{\mathrm{b}}\end{array}$ & $4^{\mathrm{a}}$ & $5^{\mathrm{a}}$ & $3^{\mathrm{b}}$ & $\begin{array}{c}6^{\mathrm{a}}+10^{\mathrm{b}} \\
128^{\mathrm{a}}+14^{\mathrm{b}}\end{array}$ \\
\hline ssp. bulgaricus & & & & & & & & & & & & & 年 & \\
\hline $\begin{array}{l}\text { Lactobacillus diolivorans } \\
\text { Lactobacillus fermentum }\end{array}$ & & $\begin{array}{l}3^{\mathrm{a}} \\
1^{\mathrm{a}}+1^{\mathrm{b}}\end{array}$ & $5^{\mathrm{b}}$ & $2^{\mathrm{a}}+3^{\mathrm{b}}$ & & $2^{\mathrm{a}}+1^{\mathrm{b}}$ & $\begin{array}{l}3^{\mathrm{a}}+2^{\mathrm{b}} \\
5^{\mathrm{a}}+6^{\mathrm{b}}\end{array}$ & $4^{\mathrm{a}}+2^{\mathrm{b}}$ & $2^{\mathrm{b}}$ & $3^{\mathrm{b}}$ & $\begin{array}{l}5^{\mathrm{a}}+1^{\mathrm{b}} \\
1^{\mathrm{a}}+2^{\mathrm{b}}\end{array}$ & $\begin{array}{l}2^{\mathrm{a}}+1^{\mathrm{b}} \\
2^{\mathrm{a}}\end{array}$ & & $\begin{array}{l}13^{\mathrm{a}}+4^{\mathrm{b}} \\
17^{\mathrm{a}}+25^{\mathrm{b}}\end{array}$ \\
\hline Lactobacillus helveticus & $1^{\mathrm{a}}+1^{\mathrm{b}}$ & $26^{\mathrm{a}}+3^{\mathrm{b}}$ & $7^{\mathrm{a}}+1^{\mathrm{b}}$ & $12^{\mathrm{a}}+4^{\mathrm{b}}$ & $5^{\mathrm{a}}+3^{\mathrm{b}}$ & $2^{a}+1^{b}$ & $11^{\mathrm{a}}+3^{\mathrm{b}}$ & $6^{\mathrm{a}}$ & $28^{\mathrm{a}}+12^{\mathrm{b}}$ & $20^{\mathrm{a}}+13^{\mathrm{b}}$ & $6^{\mathrm{a}}+2^{\mathrm{b}}$ & $8^{\mathrm{a}}+4^{\mathrm{b}}$ & $2^{\mathrm{a}}+2^{\mathrm{b}}$ & $134^{\mathrm{a}}+49^{\mathrm{b}}$ \\
\hline $\begin{array}{l}\text { Lactobacillus kefiri } \\
\text { Lactobacillus plantarum } \\
\text { ssp. plantarum }\end{array}$ & $2^{\mathrm{a}}+4^{\mathrm{b}}$ & $-2=$ & & & & & $1^{\mathrm{b}}$ & & & & & & & $\begin{array}{l}4+2^{\mathrm{a}} \\
2^{\mathrm{a}}+5^{\mathrm{b}}\end{array}$ \\
\hline $\begin{array}{l}\text { Lactococcus lactis } \\
\text { ssp. lactis }\end{array}$ & & & & & $1^{\mathrm{a}}$ & & & & $1^{\mathrm{b}}$ & & $1^{\mathrm{a}}+1^{\mathrm{b}}$ & & $2^{\mathrm{a}}+1^{\mathrm{b}}$ & $4^{\mathrm{a}}+3^{\mathrm{b}}$ \\
\hline Leuconostoc lactis & & $7^{\mathrm{a}}+5^{\mathrm{b}}$ & $1^{\mathrm{a}}+1^{\mathrm{b}}$ & $1^{\mathrm{b}}$ & $1^{\mathrm{a}}+1^{\mathrm{b}}$ & & $1^{\mathrm{a}}+1^{\mathrm{b}}$ & & $1^{\mathrm{b}}$ & $2^{\mathrm{b}}$ & & & & $9^{\mathrm{a}}+13^{\mathrm{b}}$ \\
\hline $\begin{array}{l}\text { Leuconostoc } \\
\text { mesenteroides }\end{array}$ & & & & & & $2^{\mathrm{b}}$ & & $1^{\mathrm{a}}+2^{\mathrm{b}}$ & $1^{\mathrm{a}}+1^{\mathrm{b}}$ & $2^{\mathrm{b}}$ & $3^{a}+3^{b}$ & & $1^{\mathrm{a}}+3^{\mathrm{b}}$ & $7^{\mathrm{a}}+14^{\mathrm{b}}$ \\
\hline $\begin{array}{l}\text { Streptococcus } \\
\text { thermophilus }\end{array}$ & $1^{\mathrm{a}}$ & $9^{\mathrm{a}}+9^{\mathrm{b}}$ & $1^{\mathrm{a}}+3^{\mathrm{b}}$ & $1^{\mathrm{a}}+7^{\mathrm{b}}$ & $1^{\mathrm{a}}+1^{\mathrm{b}}$ & $4^{\mathrm{a}}+12^{\mathrm{b}}$ & $5^{\mathrm{a}}+11^{\mathrm{b}}$ & $8^{a}+22^{b}$ & $24^{\mathrm{a}}+17^{\mathrm{b}}$ & $7^{\mathrm{a}}+13^{\mathrm{b}}$ & $1^{\mathrm{a}}$ & $4^{\mathrm{a}}+15^{\mathrm{b}}$ & $5^{\mathrm{a}}+14^{\mathrm{b}}$ & $70^{\mathrm{a}}+125^{\mathrm{b}}$ \\
\hline Weissella cibaria & & & & & & & & & & & & & $1^{\mathrm{b}}$ & $1^{\mathrm{b}}$ \\
\hline
\end{tabular}




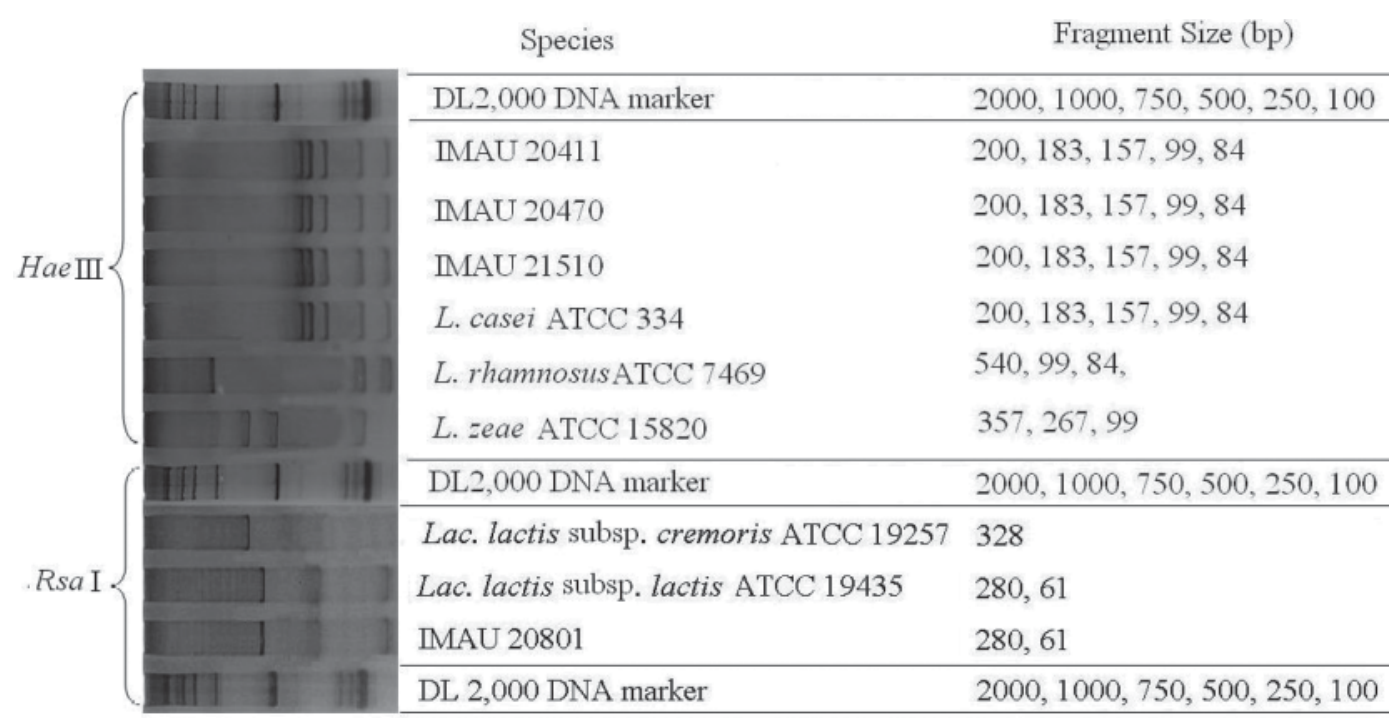

Figure 3. Polymerase chain reaction-RFLP fingerprints of Lactobacillus casei group and Lactococcus lactis strains.

mented milk of yak and mare were almost identical and were significantly higher than those in fermented goat milk but slightly lower than those in fermented cow milk. These findings are consistent with the results of previous studies. Watanabe et al. (2008) reported that the LAB counts in traditional Mongolian fermented milks airag and tarag were $7.78 \pm 0.50$ and $8.35 \pm$ $0.62 \log \mathrm{cfu} / \mathrm{mL}$, respectively. Notably, differences in the timing of milk ripening and transport or differences in sampling regions could lead to variations in LAB counts.

M17 and MRS media are used routinely for the isolation and counting of LAB from most fermented food products. Although described as a medium for the cultivation of lactobacilli, MRS has exhibited poor selectivity for lactobacilli (Ouadghiri et al., 2005). The MRS medium used in this study allowed the isolation of identified species found in fermented dairy products tested, except for E. faecalis and W. cibaria, which were isolated from M17 agar. However, more LAB isolates were obtained from MRS media (59.6\%) than from M17 agar $(40.4 \%)$, and the majority of lactobacilli $(77.1 \%)$ were isolated from MRS media, whereas the majority of cocci $(58.9 \%)$ were isolated from M17 media. Similar to our results, a prior study of LAB in yogurt demonstrated MRS as the medium of choice for differential counting of lactobacilli and M17 as the preferred medium for counting cocci (Coeuret et al., 2003).

Traditional microbiological assays are often timeconsuming and can yield variable results for the identification of closely related LAB (Ercolini, 2004). The sequencing and analysis of 16S rRNA genes is considered a cornerstone of modern microbial taxonomy (Ventura and Zink, 2002). For this reason, all isolates in this study were grouped and preliminarily identified based on their 16S rRNA gene sequences, and some closely related LAB were further examined using species- or subspecies-specific PCR primers and PCR-RFLP analysis. The results indicated that $16 \mathrm{~S}$ rRNA gene sequences of strains in the $L b$. casei group, Lb. delbrueckii group, and $L b$. plantarum group were extremely similar; however, species-specific PCR and PCR-RFLP analysis could discriminate them at the species level.

The distribution of isolates among different sampling sites is presented in Table 4. Interestingly, Strep. thermophilus and $L b$. helveticus were isolated from all sampling sites (representing 29.2 and $27.4 \%$ of all isolates, respectively), and $L b$. delbrueckii ssp. bulgaricus was isolated from most sampling sites (representing $21.4 \%$ of all isolates). In previous studies, Lb. helveticus was found to be the predominant LAB component in airag, tarag (Watanabe et al., 2008), and Mongolian koumiss (a fermented mare milk drink) (Sun et al., 2010). In comparison, Strep. thermophilus and Lb. delbrueckii ssp. bulgaricus were reported as the most frequently isolated bacteria in Columbian dairy products (Perea Veléz et al., 2007). Lactobacillus delbrueckii ssp. bulgaricus is the key organism used as a starter for the preparation of yogurt and may play a major role in coagulation of milk by rapidly increasing the acidity.

Other species isolated at relatively high frequencies included Lb. casei, Lb. fermentum, Leu. mesenteroides, Leu. lactis, and $L b$. diolivorans. Several researchers have identified $L b$. fermentum and $L b$. casei from dairy products, such as Algerian arid zone raw goat milk and Nigerian fermented foods (Olasupo et al., 2001; Guessas and Kihal, 2004). Leuconostoc mesenteroides has also been identified in Maasai traditional fermented milk 
(a)

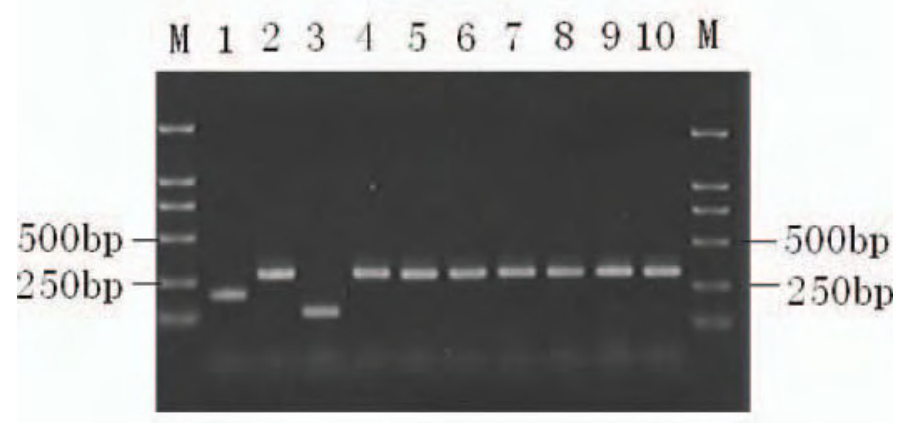

(b)

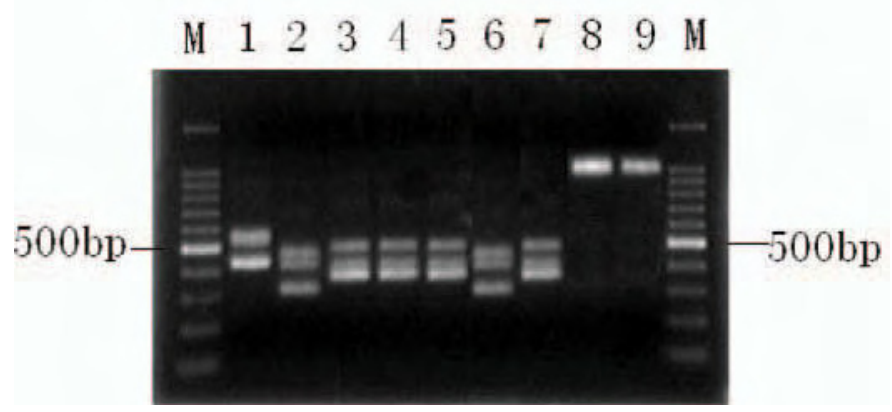

Figure 4. Amplification patterns obtained with recA gene-based multiplex primers for the Lactobacillus plantarum group (a), the intergenic transcribed spacer-PCR profiles of Enterococcus species, and the pepIP gene-based multiplex primers for Lactobacillus delbrueckii ssp. Bulgaricus (b). Panel a: $\mathrm{M}=$ DL2000 DNA marker; $1=$ Lactobacillus pentosus ATCC 8041; 2 = Lactobacillus plantarum ssp. plantarum ATCC 14917; 3 = Lactobacillus paraplantarum ATCC 700211; $4=$ IMAU70004; $5=$ IMAU70005; $6=$ IMAU70010; $7=$ IMAU70023; $8=$ IMAU70035; $9=$ IMAU70042; and $10=$ IMAU70080. Panel b: $\mathrm{M}=100$-bp DNA ladder marker; $1=$ Enterococcus faecium ATCC 19434; 2 = Enterococcus faecalis ATCC 19433; $3=$ Enterococcus durans DSM20633; $4=$ IMAU20244; $5=$ IMAU20682; $6=$ IMAU20243; $7=$ IMAU20684; 8 = Lactobacillus delbrueckii ssp. bulgaricus ATCC 11842 ; and $9=$ IMAU20255.

(Mathara et al., 2004). Leuconostoc strains naturally contribute to the development of flavor in fermented products, although they exhibit a weak competitive ability during milk fermentation due to their complex nutritional requirements. Although $L b$. diolivorans is typically isolated from maize silage (Krooneman et al., 2002), to our knowledge, it has never been reported in natural fermented milk. We isolated 17 strains of $L b$. diolivorans in this study, probably due to their complex nutritional requirements, as well as weaker adaptation to the milk environment.

In addition, a few other isolates were classified as $E$. faecalis, E. durans, Lc. lactis ssp. lactis, Lb. plantarum ssp. plantarum, Lb. kefiri, Lb. brevis, Lb. buchneri, and W. cibaria. Enterococcus faecalis, E. faecium, and to a lesser extent $E$. durans are found commonly in milk and cheese products (Franz et al., 1999). Enterococ- cus faecalis has been isolated from kajmak samples (an artisanal Serbian dairy product) and Moroccan camel milk (Benkerroum et al., 2003; Jokovic et al., 2008), whereas E. durans, originally described as an isolate of milk and dairy products (Krooneman et al., 2002), has been associated traditionally with dairy products, including cheese and fermented milk. The presence of enterococci in traditional dairy products is probably due to fecal contamination of milk during milking; however, these species are used as an additive in starter cultures for the preservation of various fermented foods, including cheese and fermented vegetable products. In the current study, 7 strains were identified as Lb. plantarum ssp. plantarum. According to Wood and Holzapfel (1995) and Stiles and Holzapfel (1997), Lb. plantarum ssp. plantarum strains are commonly associated with plant-based food fermentations. Weissella cibaria was isolated from only one fermented cow milk sample in Ulaanbaatar city, suggesting that it is likely present in low quantities. According to Isono et al. (1994), Weissella strains are found occasionally in raw milk, but their technological role in fermented milk has not been described. In general, strains of $L c$. lactis ssp. lactis are important commercial dairy starter cultures. In this study, the lowest frequency of Lc. lactis ssp. lactis was found in samples from Selenge, Dzavhan, Ovorhangay, and Ulaanbaatar provinces. Lactobacillus kefiri was detected in Sükhbaatar, Dornod, Selenge, and Bulgan provinces. In previous research, Lb. kefiri has been isolated mainly from kefir grains, but it has also been detected in some cheese varieties (Dolci et al., 2008). Lactobacillus brevis and Lb. buchneri have also been detected in fermented dairy products (Sumner et al., 1985; Rahman et al., 2009).

The complexity of the microbial composition in fermented milks appears to vary by region. We isolated 10 species of LAB in Ovorhangay province, 9 species in Bulgan province, 8 species in Dzavhan and Arhangay provinces, 7 species in Khentii, Sükhbaatar, and Selenge provinces, 6 species in Dornod and Hovsgol provinces and Ulaanbaatar city, 5 species in Hovd and Tov provinces, and only 3 species in Dornogovi. The presence of LAB with such variation of strains is not surprising because other factors may contribute to the variability of strains, such as different production methods, recipes, and raw materials. Furthermore, the environmental temperature and location differences may also cause some variation in strains.

\section{CONCLUSIONS}

This report describes the microbiological study and detailed identification of LAB involved in natural fermented milks. Streptococcus thermophilus and $L b$. 
helveticus were the dominant LAB species in fermented dairy products in Mongolia. Other species, including $E$. faecalis, E. durans, Lb. brevis, Lb. buchneri, Lb. casei, $L b$. delbrueckii ssp. bulgaricus, Lb. diolivorans, Lb. fermentum, Lb. kefiri, Lb. plantarum ssp. plantarum, Lc. lactis ssp. lactis, Leu. lactis, Leu. mesenteroides, and W. cibaria, were identified at lower frequencies. The species distribution depends on the manufacturing processes, as well as on the specific ecological locality where the milk products were manufactured. This study provides raw data and a strain resource for further studies involving probiotic strain selection and starter culture design pertaining to the industrial production of traditional fermented milk.

\section{ACKNOWLEDGMENTS}

This research was supported by National Key Technologies R\&D Program (Grant No. 2009BADC1B01), the Innovation Research Team Development Program of Ministry of Education of China (Grant No. IRT0967), the Earmarked fund for Modern Agro-industry Technology Research System (Grant No. nycytx-0501), the Key Project of Chinese Ministry of Education (Grant No. 209027) and the Prophase Research Program of 973 Project of China (973 Program) (Grant No. 2010CB134502).

\section{REFERENCES}

Abdel-Salam, A. M., A. Al-Dekheil, A. Babkr, M. Farahna, and H. M. Mousa. 2010. High fiber probiotic fermented mare's milk reduces the toxic effects of mercury in rats. North Am. J. Med. Sci. 2:569-575

Altschul, S. F., T. L. Madden, A. A. Schäffer, J. Zhang, Z. Zhang, W Miller, and D. J. Lipman. 1997. Gapped BLAST and PSI-BLAST: A new generation of protein database search programs. Nucleic Acids Res. 25:3389-3402

Barrionuevo, M., M. J. M. Alferez, I. Lopez-Aliaga, M. R. Sanz-Sampelayo, and M. S. Campos. 2002. Beneficial effect of goat milk on nutritive utilization of iron and copper in malabsorption syndrome. J. Dairy Sci. 85:657-664.

Benkerroum, N., A. Boughdadi, N. Bennani, and K. Hidane. 2003. Microbiological quality assessment of Moroccan camel's milk and identification of predominating lactic acid bacteria. World J. Microbiol. Biotechnol. 14:645-648.

Caplice, E., and G. F. Fitzgerald. 1999. Food fermentations: Role of microorganisms in food production and preservation. Int. J. Food Microbiol. 50:131-149.

Coeuret, V., S. Dubernet, M. Bernardeau, M. Gueguen, and J. P. Vernoux. 2003. Isolation, characterisation and identification of lactobacilli focusing mainly on cheeses and other dairy products. Lait 83:269-306.

Corsetti, A., L. Settanni, C. C. López, G. E. Felis, M. M. Mastrangelo, and G. Suzzi. 2007. A taxonomic survey of lactic acid bacteria isolates from wheat (Triticum durum) kernels and non-conventional flours. Syst. Appl. Microbiol. 30:561-571.

Dolci, P., V. Alessandria, K. Rantsiou, L. Rolle, G. Zeppa, and L. Cocolin. 2008. Microbial dynamics of Castelmagno PDO, a traditional Italian cheese, with a focus on lactic acid bacteria ecology. Int. J. Food Microbiol. 122:302-311.
Ercolini, D. 2004. PCR-DGGE fingerprinting: Novel strategies for detection of microbes in food. J. Microbiol. Methods 56:297-314.

Fortina, M. G., G. Ricci, A. Acquati, G. Zeppa, A. Gandini, and P. L. Manachini. 2003. Genetic characterization of some lactic acid bacteria occurring in an artisanal protected denomination origin (PDO) Italian cheese, the Toma Piemontese. Food Microbiol 20:397-404.

Franz, C. M., W. H. Holzapfel, and M. E. Stiles. 1999. Enterococci at the crossroads of food safety? Int. J. Food Microbiol. 47:1-24.

Fratkin, E. 2005. A comparative approach to transition and social change among livestock pastoralists in east Africa and central Asia. Senri Ethnol. Stud. 69:15-29.

Geerlings, A., I. C. Villar, F. Hidalgo Zarco, M. Sánchez, R. Vera A. Zafra Gomez, J. Boza, and J. Duarte. 2006. Identification and characterization of novel angiotensin-converting enzyme inhibitors obtained from goat milk. J. Dairy Sci. 89:3326-3335.

Guessas, B., and M. Kihal. 2004. Characterization of lactic acid bacteria isolated from Algerian arid zone raw goat's milk. Afr. J. Biotechnol. 3:339-342.

Isono, Y.. I. Shingu, and S. Shimizu. 1994. Identification and characteristics of lactic acid bacteria isolated from Maasai fermented milk in northern Tanzania. Biosci. Biotechnol. Biochem. 58:660-664.

Jokovic, N., M. Nikolic, J. Begovic, B. Jovcic, D. Savic, and L. Topisirovic. 2008. A survey of the lactic acid bacteria isolated from Serbian artisanal dairy product kajmak. Int. J. Food Microbiol. 127:305-311.

Kozaki, M., T. Uchimura and S. Okada. 1992. Experimental Manual of Lactic Acid Bacteria. Asakurasyoten, Tokyo, Japan.

Krooneman, J., F. Faber, A. C. Alderkamp, S. J. H. W. Oude Elferink, F. Driehuis, I. Cleenwerck, J. Swings, J. C. Gottschal, and M. Vancanneyt. 2002. Lactobacillus diolivorans sp. nov., a 1, 2-propanediol-degrading bacterium isolated from aerobically stable maize silage. Int. J. Syst. Evol. Microbiol. 52:639-646.

Lozovich, S. 1995. Medical use of whole and fermented mare milk in Russia. Cult. Dairy Prod. J. 30:18-21.

Martín-Diana, A. B., C. Janer, C. Peláez, and T. Requena. 2003. Development of a fermented goat's milk containing probiotic bacteria. Int. Dairy J. 13:827-833.

Mathara, J. M., U. Schillinger, P. M. Kutima, S. K. Mbugua, and W H. Holzapfel. 2004. Isolation, identification and characterisation of the dominant microorganisms of kule naoto: the Maasai traditional fermented milk in Kenya. Int. J. Food Microbiol. 94:269-278.

Olasupo, N. A., U. Schillinger, and W. H. Holzapfel. 2001. Studies on some technological properties of predominant lactic acid bacteria isolated from Nigeria fermented foods. Food Biotechnol. 15:157167.

Ouadghiri, M., M. Amar, M. Vancanneyt, and J. Swings. 2005. Biodiversity of lactic acid bacteria in Moroccan soft white cheese (Jben). FEMS Microbiol. Lett. 251:267-271.

Perea Vélez, M., K. Hermans, T. L. A. Verhoeven, S. E. Lebeer, J. Vanderleyden, and S. C. J. De Keersmaecker. 2007. Identification and characterization of starter lactic acid bacteria and probiotics from Columbian dairy products. J. Appl. Microbiol. 103:666-674.

Rahman, N., C. Xiaohong. F. Meiqin, and D. Mingsheng. 2009. Characterization of the dominant microflora in naturally fermented camel milk shubat. World J. Microbiol. Biotechnol. 25:1941-1946.

Solaroli, G., E. Pagliarini, and C. Peri. 1993. Compositional and nutritional quality of mare's milk. Ital. J. Food Sci. 5:3-10.

Sternberg, T. 2008. Environmental challenges in Mongolia's dryland pastoral landscape. J. Arid Environ. 72:1294-1304.

Stiles, M. E., and W. H. Holzapfel. 1997. Lactic acid bacteria of food and their current taxonomy. Int. J. Food Microbiol. 36:1-29. (Review).

Sumner, S. S., M. W. Speckhard, E. B. Somers, and S. L. Taylor. 1985. Isolation of histamine-producing Lactobacillus buchneri from Swiss cheese implicated in a food poisoning outbreak. Appl. Environ. Microbiol. 50:1094-1096.

Sun, Z. H., W. J. Liu, J. C. Zhang, J. Yu, W. Gao, M. T. Jiri, B. Menghe, T. S. Sun, and H. P. Zhang. 2010. Identification and characterization of the dominant lactic acid bacteria isolated from 
traditional fermented milk in Mongolia. Folia Microbiol. (Praha) 55:270-276.

Tamura, K., J. Dudley, M. Nei, and S. Kumar. 2007. MEGA4: Molecular evolutionary genetics analysis (MEGA) software version 4.0. Mol. Biol. Evol. 24:1596-1599.

Torriani, S., G. E. Felis, and F. Dellaglio. 2001. Differentiation of Lactobacillus plantarum, L. pentosus and $L$. paraplantarum by recA gene sequence analysis and multiplex PCR assay with recA gene derived primers. Appl. Environ. Microbiol. 67:3450-3454.

Torriani, S., G. Zapparoli, and F. Dellaglio. 1999. Use of PCR-based methods for rapid differentiation of Lactobacillus delbrueckii ssp. bulgaricus and L. delbrueckii ssp. lactis. Appl. Environ. Microbiol. 65:4351-4356.

Uchida, K., M. Hirata, H. Motoshima, T. Urashima, and I. Arai. 2007. Microbiota of 'airag', 'tarag' and other kinds of fermented dairy products from nomad in Mongolia. Anim. Sci. J. 78:650-658.

Ventura, M., C. Canchaya, V. Meylan, T. R. Klaenhammer, and R. Zink. 2003. Analysis, characterization, and loci of the tuf genes in Lactobacillus and Bifidobacterium species and their direct application for species identification. Appl. Environ. Microbiol. 69:6908-6922.
Ventura, M., and R. Zink. 2002. Specific identification and molecular typing analysis of Lactobacillus johnsonii by using PCR-based methods and pulsed-field gel electrophoresis. FEMS Microbiol. Lett. 217:141-154.

Watanabe, K., J. Fujimoto, M. Sasamoto, J. Dugersuren, T. Tumursuh, and S. Demberel. 2008. Diversity of lactic acid bacteria and yeasts in Airag and Tarag, traditional fermented milk products of Mongolia. World J. Microbiol. Biotechnol. 24:1313-1325.

Weisburg, W. G., S. M. Barns, D. A. Pelletier, and D. J. Lane. 1991. $16 \mathrm{~S}$ ribosomal DNA amplification for phylogenetic study. J. Bacteriol. 173:697-703.

Wood, B. J. B., and W. H. Holzapfel. 1995. The Genera of Lactic Acid Bacteria. Vol. 2. Blackie Academic \& Professional, Glasgow, UK.

Young, J. P. W., H. L. Downer, and B. D. Eardly. 1991. Phylogeny of the phototrophic Rhizobium strain BTAil by polymerase chain reaction-based sequencing of a $16 \mathrm{~S}$ rRNA gene segment. J. Bacteriol. 173:2271-2277.

Yu, J., Z. H. Sun, W. J. Liu, J. C. Zhang, T. S. Sun, Q. H. Bao, and H. P. Zhang. 2009. Rapid identification of lactic acid bacteria isolated from homemade fermented milk in Tibet. J. Gen. Appl. Microbiol. $55: 181-190$. 